\title{
UN: A Sunrise Organization?
}

\begin{abstract}
As the UN commemorates its 75th anniversary, few today see it as a beacon of hope. To revive the fortunes of the UN, greater financial support and more inclusive reforms to the General Assembly and the Security Council will make it truly indispensable to solving the common challenges facing humanity today.
\end{abstract}

In 2000, I was the Singapore Ambassador to the United Nations when the UN General Assembly (UNGA) unveiled its Millennium Development Goals (MDGs). Kofi Annan was UN Secretary-General. Bill Clinton was the US president. It was a time of great hope. Everyone believed that the UN represented the only vehicle for humanity to come together and cooperate. By contrast, even though many world leaders, including Chinese President Xi Jinping and US President Donald Trump, addressed the UNGA by video at the special commemoration of the 75th Anniversary, the air of doom and gloom surrounding the UN was clear and palpable. Few believe today that the UN still functions as a beacon of hope.

This conventional wisdom of pessimism on the UN is dead wrong. If there is one global organization that has become indispensable for humanity, it is the UN! Why so? Covid-19 has sent humanity a clear metaphysical message. All of humanity is now in the same boat. In the past, when 7.7 billion people lived in 193 separate countries, it was as though they were living in 193 separate boats. Now they live in 193 separate cabins on the same boat. This is why Covid-19 could spread from one end of planet Earth to another in a matter of months.

There is only one problem with our global boat. We have governments taking care of each cabin. We have no strong institutions of global governance to manage our global boat as a whole. The only organization which enjoys the universal representation of humanity and can provide such global leadership is the UN. In a small, shrinking, interdependent planet Earth, the UN has become an indispensable organization. Hence it will grow as a sunrise organization in the twenty-first century.

Originally published in China Daily, Sep 23, 2020 
Still, it faces real challenges. The most powerful country, the United States, has become disillusioned with the UN. At the height of Covid-19, when humanity needed to cooperate to fight it, the US left WHO (after leaving UNESCO earlier). It has paralyzed the WTO.

Can we persuade the US to support the UN again? Yes, we can. In 2003, President Bill Clinton gave a powerful speech in Yale University. He said that if the US was going to be the number one country forever, it could continue behaving unilaterally. Yet, if the US could conceive of becoming number two, it would be in the long-term national interest of the US to "create a world with rules, partnerships, and habits of behavior" that the US would like to live in if and when it becomes number two. In due course, American pundits and policymakers will come to accept the wisdom contained in Bill Clinton's advice.

Yet, the UN cannot rest on its laurels. It needs to constantly reinvent and reform itself. As the new rising power, China can help to provide some quiet leadership in UN reform, especially since China believes in a "community of shared future". Every community needs a parliament where members can share their views, discuss, compromise and reach a consensus. The only functioning global parliament is the UNGA. Working with other key stakeholders, like the EU, the African Union, Latin America, India, and ASEAN, China can help to quietly revive the UNGA.

Similarly, the UN Security Council (UNSC) needs reform. It was wise of the founding fathers of the UN to give the great powers a veto in the UNSC as it gave them a powerful stake in the UN. This is why the US has not left the UN, even though it left the League of Nations. However, the veto power was intended for the great powers of today and tomorrow, not the great powers of yesterday. UNSC reform is difficult. The biggest obstacle is the lack of agreement on who should be the new permanent members.

This is why, in my book, The Great Convergence, I proposed a new formula of seven permanent members, seven semi-permanent members, and seven elected members. This 7-7-7 formula will bring in India, Brazil and an African state (to be chosen by Africa) as permanent members. Getting India in is key. As Martin Wolf of the Financial Times wisely said, "Exhausted by the burden of its pretensions, the UK should soon offer its seat on the security council of the United Nations to its former colony."

Finally, the finances of the UN need to be fixed. The European Union (EU) members believe in the UN but they have been strangling the necessary funding for the UN because they believe they pay too much. Unwisely, the EU led the charge to reduce mandatory contributions to the WHO from $62 \%$ in $1970-71$ to less than $20 \%$ today.

To address these grievances of the EU, we must reduce the percentage of Western funding to the UN. The West European and Other States Group represent only $12 \%$ of the world's population but they contribute over $50 \%$ of the UN Budget. This should stop. Asians, who represent over $50 \%$ of the world's population, should pay more. 
In his speeches, President Xi has announced generous voluntary contributions to key UN projects. It would be good for other Asian states to follow China's example in announcing their willingness to contribute more to the UN system. This could strengthen the UN and make it once again a beacon of hope. Asians can then feel proud that in the twenty-first century, the Asian Century, they led the way in reviving and rejuvenating the $\mathrm{UN}$.

Open Access This chapter is licensed under the terms of the Creative Commons AttributionNonCommercial-NoDerivatives 4.0 International License (http://creativecommons.org/licenses/bync-nd/4.0/), which permits any noncommercial use, sharing, distribution and reproduction in any medium or format, as long as you give appropriate credit to the original author(s) and the source, provide a link to the Creative Commons license and indicate if you modified the licensed material. You do not have permission under this license to share adapted material derived from this chapter or parts of it.

The images or other third party material in this chapter are included in the chapter's Creative Commons license, unless indicated otherwise in a credit line to the material. If material is not included in the chapter's Creative Commons license and your intended use is not permitted by statutory regulation or exceeds the permitted use, you will need to obtain permission directly from the copyright holder.

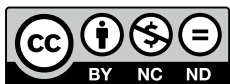

